Not the last word

\section{London}

THE British government's long-awaited white paper (policy document) on environmental policy, released last week under the title This Common Inheritance*, is under fire from opposition parties and environmentalist pressure groups for proposing few new initiatives to address global warming and other environmental problems. But Environment Secretary Chris Patten asserts that "this is not our last word on the environment", suggesting that the government may produce a more radical package in the future.

The white paper draws together existing initiatives in an overall strategy to protect the environment and promises that a minister from each government department will be responsible for its implementation. On the central issue of meeting Britain's stated target of stabilizing the emission of carbon dioxide at 1990 levels by 2005 , the white paper rejects the introduction of a 'carbon tax' on fossil fuels in the next few years. A carbon tax is thought to be unacceptable politically to a government poised to sell the electricity industry to private investors as a high-profit concern.

In the short term, energy efficiency will be given a higher profile, under a new ministerial committee chaired by Energy Secretary John Wakeham, and the activities of the Energy Efficiency Office (which has seen its budget decline to $£ 15$ million in 1989-90, from the peak in 198687 of $£ 26$ million) will be stepped up.

A proposal from the UK Chemical Industries Association to replace the current multiplicity of UK pollution inspectorates with a single environmental protection agency, accountable to parliament, has not been accepted by the government. The association argues that a more single-minded approach would give the United Kingdom a stronger voice within the European Communities in framing environmental regulations.

The government has chosen to avoid this upheaval. But Her Majesty's Inspectorate of Pollution, responsible for policing industrial pollution to land and air, will be given a new advisory committee aid greater independence from the Department of the Environment, in the hope that this will combat the inspectorate's widely publicized poor morale.

Patten was significantly less bullish at the launch of the new white paper than at the publication of the government's Environment Protection Bill in December last year. That bill created the foundations for pollution control in the United

*The white paper This Common Inheritance $(\mathrm{Cm}$ 1200 ) is published at $£ 24.50$ by HMSO, inclusive of a 36-page summary. The summary booklet is available separately at $£ 2.50$. Telephone orders accepted on 071-873-9090.

Kingdom "well into the next century", he said. Last week, his vision was limited to laying the foundations of environmental policy "for the next few years".

But a close reading of the 300-page white paper points to a number of policies that may be introduced in the longer term. The potential for 'market instruments' CARBON DIOXIDE EMISSIONS

\title{
Taxation or regulation?
}

\section{London}

THE decision of the UK government to avoid carbon taxes for the time being, announced in its new white paper (see above), will do little to settle the international debate over whether taxation or regulation will provide the best method to reduce the emission of greenhouse gases. In the United States and Europe, opinions now seem to be diverging on the most efficient policy instruments, and there are signs that different countries may head in quite different directions.

Stewart Boyle, from the UK Association for the Conservation of Energy, argues that regulations and increased subsidies to finance the initial cost of energyefficiency improvements will be needed in addition to a carbon tax in order to meet the British target of stabilizing UK carbon dioxide emissions at 1990 levels by 2005 . He points to studies showing that, during the $1970 \mathrm{~s}$, successive petrol price rises each decreased fuel consumption by British motorists for only a short period.

In California, opposition to a proposal to cut the state's carbon dioxide emissions by 40 per cent before 2010 (see Nature 347, 323; 25 September 1990) has centred around the size of carbon tax required to meet the target. Opponents of the move calculate that petrol (gasoline) would need to be increased in price by up to 70 cents per gallon and electricity bills by 20 per cent by 2000 .

William Nordhaus, an economist from Yale University, says that both sides in the California debate are using "advocacy economics", rather than objective analysis. Looking at the United States as a whole, he says significant reductions will be costly whatever measures are taken, but Nordhaus maintains it is probably "twice as expensive" to achieve cuts in emissions through regulation rather than by taxation. The problem with regulations, Nordhaus explains, is that their effect is limited to individual sources of emissions, such as car exhausts, whereas carbon taxes can influence fuel use throughout the economy. Tax rises, in whatever form, are nevertheless so unpopular with the electorate that governments may prefer a limited package of regulations. (such as the much vaunted carbon tax) in cutting pollutant emissions "will be pursued with vigour", and these are discussed in an annexe to the main paper. Patten's 'special adviser', Professor David Pearce, an economist at University College London, has espoused these ideas for some time, but this is the first time they have received official recognition in a government policy document.

Peter Aldhous
Regulation to enforce energy efficiency standards is central to the Dutch strategy. The Netherlands is aiming to stabilize its carbon dioxide emissions at 1989-90 levels by 1995 , with real reductions by the end of the century. Low-rate carbon taxes were introduced earlier this year (0.27 Dutch guilders on each 100 litres of petrol; G2.61 per tonne of coal), but the primary aim of these is to raise funds to finance environmental protection schemes and subsidies, rather than to have a real effect on fuel use.

In Britain, the merit of carbon taxes is not the only uncertainty surrounding the government's carbon dioxide emissions target - there is disagreement over the extent to which UK emissions will grow if no action is taken. The government's official position is based on a Department of Energy study which predicted an increase of 30 per cent by 2005 . But this is widely dismissed as unrealistic, and the Department of the Environment is thought to be

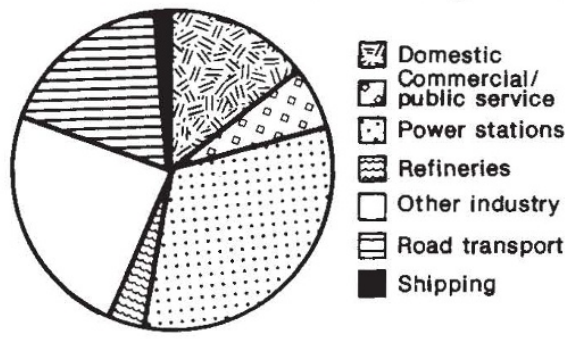

Carbon dioxide emissions from the UK.

working on a 'business as usual' increase nearer to 20 per cent by 2005 . Gerald Leach, who has completed an analysis of UK carbon dioxide emissions for the Stockholm Environment Institute, says that even this figure may be too high. Extrapolating forward from current trends in energy use and efficiency, he calculates an increase in UK emissions of less than 12 per cent between 1987 and 2005.

Peter Aldhous

\section{Correction: Greenhouse gases}

THE table in the 13 September news item "Room for improvement on emissions" gave total greenhouse gas emissions for a number of countries in millions of tonnes of carbon equivalent. The correct figures should be thousands of millions of tonnes. The per capita figures are correct. 